\title{
PENGARUH CORPORATE SOCIAL RESPONSIBILITY DISCLOSURE DAN PROFITABILITAS TERHADAP NILAI PERUSAHAAN PADA PT UNILEVER INDONESIA YANG TERDAFTAR DI BURSA EFEK INDONESIA
}

\author{
Oleh: \\ Rocky Sanjaya \\ S1 Akuntansi \\ Parman Tarigan, Liper Siregar, Jubi
}

Abstraksi

Tujuan dari penelitian ini adalah untuk untuk mengetahui gambaran corporate social responsibility disclosure, profitabilitas, dan nilai perusahaan serta pengaruh corporate social responsibility disclosure dan profitabilitas terhadap nilai perusahaan pada PT Unilever Indonesia, Tbk yang terdaftar di Bursa Efek Indonesia baik secara simultan maupun parsial. Metode analisis yang digunakan dalam penelitian ini adalah metode analisis deskriptif kualitatif dan kuantitatif. Objek penelitian ini adalah PT Unilever Indonesia, Tbk terdaftar di Bursa Efek Indonesia periode 2006-2014. Teknik analisis kuantitatif yang digunakan adalah regresi linear berganda, koefisien korelasi dan determinasi, uji F dan uji t. Analisis data dilakukan dengan menggunakan bantuan software statistic SPSS 19.

Hasil analisa dari regresi linier berganda yaitu: $\mathrm{Y}=-537,297+568,974 \mathrm{X} 1+411,042 \mathrm{X} 2+\varepsilon$. Hal ini menunjukkan bahwa corporate social responsibility disclosure yang diproksikan dengan $\mathrm{NH}$ Aprroach dan profitabilitas yang diproksikan dengan Return On Assets (ROA) berpengaruh positif terhadap nilai perusahaan yang diproksikan dengan Market to Book Ratio (MBR). Hasil kolerasi antar variabel yaitu $\mathrm{r}=0,834$ menunjukkan bahwa hubungan koefisien korelasi sangat kuat. Dari koefisien determinasi MBR dapat dijelaskan oleh corporate social responsibility disclosure dan profitabilitas sebesar $69,6 \%$ dan sisanya sebesar $30,4 \%$ dipengaruhi oleh variabel lainn yang tidak dimasukkan dalam model penelitian ini. Hipotesis penelitian $\mathrm{H}_{0}$ ditolak dengan tingkat signifikansi $0,028<0,05$, yang berarti bahwa corporate social responsibility disclosure dan profitabilitas berpengaruh signifikan secara simultan terhadap nilai perusahaan pada PT. Unilever Indonesia, Tbk yang terdaftar di Bursa Efek Indonesia tahun 2006-2014.

Kata Kunci: Corporate Social Responsibility Disclosure, Profitabilitas, dan Nilai Perusahaan

\section{Abstraction}

The purpose of this research are to identify the description of corporate social responsibility disclosure, profitability and firm value and analyze the effect of corporate social responsibility disclosure and profitability to firm value at PT Unilever Indonesia, Tbk listed in Indonesia Stock Exchange either simultanly or partially. Methods of analysis used in this study are descriptive analysis of qualitative methods and quantitative descriptive analysis. The object of this research is PT Unilever Indonesia, Tbk in 2006-2014. Analytical quantitative techniques used are multiple linear regression, correlation and coefficient of determination, F-test and t-test. Data analysis was done using SPSS statistic software assistance 19.

Result of analysis multiple linear regression that is $\mathrm{Y}=-537,297+568,974 \mathrm{X} 1+411,042 \mathrm{X} 2+\varepsilon$. This shows that corporate social responsibility is proxied by $\mathrm{NH}$ Aprroach and profitability is proxied by Return On Assets (ROA) has a positive effect on the firm value is proxied by Market to Book Ratio (MBR). The test results of correlation among variables obtained equal to 0.834 indicates a very strong of the correlation coefficient. From coefficient determination MBR can be explained by the corporate social responsibility disclosure and profitability of 69,6\%, while 30,4\% is explained by other variables are not included in the model of this research. The research hypothesis $H_{0}$ is rejected with the significance level 0.028 is smaller than 5\% or 0,05, means that corporate social responsibility disclosure and profitability had significant effect to the firm value at PT Unilever Indonesia are listed in Indonesia Stock Exchange from 2006 until 2014.

Keywords: Corporate Social Responsibility (CSR) Disclosure, Profitability and Firm Value

\section{A. PENDAHULUAN}

1. Latar Belakang Masalah

Sebuah perusahaan yang baik harus mampu mengontrol potensi finansial maupun potensi non finansial di dalam meningkatkan nilai perusahaan untuk eksistensi perusahaan dalam jangka panjang. Nilai perusahaan dapat didefinisikan sebagai nilai wajar perusahaan yang menggambarkan persepsi investor terhadap emiten bersangkutan. Harga pasar yang tinggi membuat nilai perusahaan juga tinggi. Menurut Keown (2004:470), nilai perusahaan merupakan nilai pasar atas surat berharga, hutang, dan ekuitas pemegang saham yang beredar. Salah satu rasio yang digunakan untuk mengukur nilai perusahaan adalah Market to Book Ratio yakni rasio dan nilai pasar per lembar saham biasa atas nilai buku per lembar ekuitas.

\begin{tabular}{lllll}
\hline Jurnal SULTANIST & ISSN : 2338-4328 & Vol. 4, No. 1, & JUNI 2016 & 58
\end{tabular}


Menurut McWilliams dan Siegel (2000) kondisi keuangan yang baik ternyata tidak cukup menjamin nilai perusahaan tumbuh secara berkelanjutan. Keberlanjutan perusahaan (corporate sustainability) hanya akan terjamin apabila perusahaan memperhatikan dimensi sosial dan lingkungan hidup. Pentingnya Corporate Social Responsibility sebagai bentuk etika bisnis perusahaan yang berarti bahwa perusahaan tidak hanya mempunyai kewajiban-kewajiban ekonomi tetapi juga kewajiban sosial dan lingkungan akibat dari kegiatan operasionalnya. Menurut Hadi (2011:48), Corporate Social Responsibility adalah satu bentuk tindakan yang berangkat dari pertimbangan etis perusahaan yang diarahkan untuk meningkatkan ekonomi, yang diikuti dengan peningkatan kualitas hidup karyawan berikut keluarganya, serta sekaligus peningkatan kualitas hidup masyarakat sekitar dan masyarakat secara lebih luas.

Dalam hal finansial, berbagai aspek keuangan di dalam perusahaan berpengaruh signifikan terhadap nilai perusahaan, salah satunya adalah rasio profitabilitas. Paradigma yang dianut oleh banyak perusahaan dewasa ini mengacu pada profit oriented. Perusahaan yang dapat memperoleh laba besar dapat dikatakan berhasil atau memiliki kinerja keuangan yang baik. Sebaliknya apabila laba yang diperoleh perusahaan relatif kecil, maka dapat dikatakan perusahaan kurang berhasil atau kinerja yang kurang baik. Hal ini dikarenakan profitabilitas adalah hasil akhir dari sejumlah kebijakan dan keputusan manajemen perusahaan.

\section{Rumusan Masalah}

a. Bagaimana gambaran corporate social responsibility disclosure, profitabilitas, dan nilai perusahaan pada PT. Unilever Indonesia Tbk yang terdaftar di Bursa Efek Indonesia ?

b. Bagaimana pengaruh corporate social responsibility disclosure dan profitabilitas terhadap nilai perusahaan pada PT. Unilever Indonesia Tbk yang terdaftar di Bursa Efek Indonesia?

\section{Tujuan Penelitian}

a. Untuk mengetahui gambaran corporate social responsibility disclosure, profitabilitas, dan nilai perusahaan pada PT. Unilever Indonesia Tbk yang terdaftar di Bursa Efek Indonesia.

b. Untuk mengetahui dan menganalisis pengaruh corporate social responsibility disclosure dan profitabilitas terhadap nilai perusahaan pada PT. Unilever Indonesia Tbk yang terdaftar di Bursa Efek Indonesia.

\section{Metode Penelitian}

Dalam penelitian ini, penulis mengambil objek penelitian pada PT. Unilever Indonesia, Tbk yang terdaftar di Bursa Efek Indonesia yang beralamat di Jl. Jend. Sudirman Kav 52-53 Jakarta Selatan 12190, Indonesia.
Adapun Desain penelitian yang digunakan dalam penulisan skripsi ini adalah Penelitian Kepustakaan (Library Research). Teknik pengumpulan data yang dilakukan penulis dalam penelitian ini adalah dokumentasi. Adapun jenis data yang digunakan dalam penelitian ini adalah jenis data kualitatif dan data kuantitatif. Teknik analisis data yang digunakan dalam penelitian ini terdiri dari analisis deskriptif dan induktif

\section{B. LANDASAN TEORI}

\section{Laporan Keuangan}

Menurut Kasmir (2010:66), laporan keuangan adalah laporan yang menunjukkan kondisi perusahaan pada saat ini atau dalam suatu periode tertentu. Menurut PSAK tahun 2011 (Martani, et. al, 2012:10), laporan keuangan terdiri dari beberapa jenis yaitu:

a. Laporan Posisi Keuangan adalah daftar yang sistematis dari aset, utang, dan modal pada tanggal tertentu, yang biasanya dibuat pada akhir tahun.

b. Laporan Laba Rugi komprehensif adalah ikhtisar mengenai pendapatan dan beban suatu entitas untuk periode tertentu, sehingga dapat diketahui laba yang diperoleh dan rugi yang dialami.

c. Laporan arus Kas, dengan adanya laporan ini, pemakai laporan keuangan dapat mengevaluasi perubahan aset netto entitas, struktur keuangan (termasuk likuiditas dan solvabilitas) dan kemampuan entitas untuk menghasilkan kas di masa mendatang.

d. Laporan perubahan Ekuitas adalah laporan yang menunjukkan perubahan ekuitas untuk periode tertentu, bisa satu bulan atau satu tahun.

e. Catatan atas Laporan Keuangan merupakan laporan yang berisi informasi tambahan atas apa yang disajikan dalam empat laporan diatas.

\section{Corporate Social Responsibility Disclosure}

Menurut Hadi (2011:48), Corporate Social Responsibility adalah satu bentuk tindakan yang berangkat dari pertimbangan etis perusahaan yang diarahkan untuk meningkatkan ekonomi, yang diikuti dengan peningkatan kualitas hidup karyawan berikut keluarganya, serta sekaligus peningkatan kualitas hidup masyarakat sekitar dan masyarakat secara lebih luas.

Instrumen pengukuran Corporate Sosial Responsibility Disclosure dalam penelitian ini mengacu pada instrumen yang digunakan oleh Hadi (2011:189), yakni menggunakan NH Aprroach yang merupakan teknik pengukuran yang digunakan untuk mengukur kinerja sosial perusahaan yang membagi informasi pengungkapan tanggungjawab sosial ke dalam 6 kategori yaitu lingkungan, energy, community, employee, product, dan bentuk lainnya. Kategori tersebut terbagi atas 67 item pengungkapan, yang disesuaikan dengan masing-masing sektor industri sehingga item pengungkapan yang diharapkan dari setiap sektor berbeda-beda. Pada dasarnya, untuk menghitung $N H$ Aprroach dapat 
mengunakan pendekatan dikotomi yaitu setiap item CSR dalam instrumen penelitian diberi nilai 0 jika tidak diungkapkan dan nilai 1 jika diungkapkan. Selanjutnya, skor dari selurth item yang diungkapkan akan dijumlahkan untuk memperoleh keseluruhan skor untuk setiap perusahaan.

\section{NH Approach $=\frac{\text { Aktivitas CSR yang diungkapkan }}{\text { jumlah item aktivitas CSR }}$}

\section{Profitabilitas}

Menurut Kasmir (2010:115), profitabilitas dapat dikatakan sebagai kemampuan perusahaan dalam mencari keuntungan dari aktivitas yang dilakukan pada periode akuntansi. Jenis-jenis rasio profitabilitas menurut Kasmir (2010:115), adalah sebagai berikut:

a. Profit Margin (Profit Margin On Sales)

Merupakan salah satu rasio yang digunakan untuk mengukur margin laba atas penjualan. Profit Margin On Sales $=$ Laba setelah pajak $\mathrm{X} 100 \%$$$
\text { Penjuala }
$$

b. Retwrn On Assets (ROA)

Mcrupakan suatu ukuran untuk menilai seberapa besar pertumbuhan penjualan dari aset yang dimiliki.

$$
R O A=\frac{\text { Laba setelah pajak }}{\text { Total aset }} \times 100 \%
$$

c. Return On Equity (ROE)

Merupakan rasio untuk mengukur laba bersih setelah pajak dengan modal sendiri.

$$
R O E=\frac{\text { Laba setelah pajak }}{\text { Total ekuitas }} \times 100 \%
$$

d. Earning Per Share of Commont Stock (Rasio per lembar saham)

Merupakan rasio untuk mengukur keberhasilan manajemen dalam mencapai keuntungan bagi pemegang saham.

$$
E P S=\frac{\text { Laba saham biasa }}{\text { Saham biasa yang beredar }}
$$

e. Rasio Pertumbuhan

Merupakan rasio yang menggambarkan kemampuan perusahaan mempertahankan posisi ekonominya di tengah pertumbuhan perekonomian dan sektor usahanya.

f. Rasio Penilaian

Rasio penilaian yaitu rasio yang memberikan ukuran kemampuan manajemen menciptakan nilai pasar usahanya diatas investasi.

Dalam penelitian ini profitabilitas diproksikan melalui return on assets (ROA) sebagai ukuran profitabilitas perusahaan.

\section{Nilai Perusahaan}

Nilai perusahaan merupakan harga yang bersedia dibayar oleh investor atau calon pembeli apabila perusahaan tersebut dijual (Husnan dan Pudjiastuti, 2004:6). Menurut Sudana (2011:23), rasio nilai perusahaan terdiri dari:

\section{a. Price Earning Ratio (PER)}

Rasio ini mengukur bagaimana investor menilai prospek pertumbuhan perusahaan di masa yang akan datang, dan tercermin pada harga saham yang bersedia di bayar oleh investor untuk setiap rupiah laba yang diperoleh perusahaan.

$$
P E R=\frac{\text { market price per share }}{\text { earning per share }}
$$

b. Dividend Yield

Rasio ini mengukur seberapa besar tingkat keuntungan berupa dividen yang mampu dihasilkan dari investasi pada saham.

$$
\text { Dividend Yield }=\frac{\text { Dividen per share }}{\text { market price per share }}
$$

c. Divident Payout Ratio (DPR)

Rasio ini mengukur berapa besar bagaian laba bersih setelah pajak yang dibayarkan sebagai dividen pemegang saham.

Dividen Payout Ratio

$$
=\frac{\text { Dividen }}{\text { earning after taxes }}
$$

d. Market to Book Ratio (MBR)

Rasio ini mengukur penilaian pasar keuangan terhadap manajemen dan organisasi perusahaan sebagai going concern. Untuk mendapatkan rasio ini, terlebih dahulu kita menghitung nilai buku per lembar saham yang dinyatakan sebagai berikut:

Nilai buku per saham

$$
=\frac{\text { Ekuitas biasa }}{\text { jumlah saham beredar }}
$$

Selanjutnya untuk menghitung rasio nilai pasar digunakan cara berikut:

Rasio nilai pasar/nilai buku (M/B)

$$
=\frac{\text { harga pasar saham }}{\text { nilai buku per saham }}
$$

Dalam penelitian ini nilai perusahaan diproksikan melalui Market to Book Ratio sebagai ukuran nilai perusahaan.

\section{Pengaruh Corporate Social Responsibility Disclosure dan Profitabilitas terhadap Nilai Perusahaan}

Menurut Hadi (2011:127), tanggungjawab sosial perusahaan didudukkan sebagai strategi bisnis perusahaan berarti perusahaan menggunakan tanggungjawab sosial perusahaan sebagai media konstruksi strategi bisnis. Perusahaan banyak menggunakan simbol-simbol dan dimensi social responsibility dalam membangun nilai perusahaan. Kedekatan dengan para stakeholders (konsumen, suplier, masyarakat sekitar dan lingkungan fisik sekitar) dapat membangun keunggulan kompetitif perusahaan dalam peningkatan nilai perusahaan.

Menurut Achmad (2004:47), adanya pertumbuhan return on assets diharapkan terjadi kenaikan harga saham yang lebih besar daripada kenaikan earning karena adanya prospek perusahaaan yang semakin baik. Jika investor ingin melihat seberapa besar perusahaan menghasilkan pengembalian atas investasi yang akan mereka tanamkan, maka yang pertama kali dilihat adalah rasio profitabilitasnya. Semakin tinggi ROA berarti kinerja perusahaan semakin efektif, karena tingkat 
kembalian investasi atas aset semakin besar (Brigham dan Joel, 2009:107).

\section{PEMBAHASAN}

\section{Analisa}

\section{a. Uji Asumsi Klasik}

Uji normalitas dengan pengujian One Sample Kolmogorov-Smirnov diperoleh nilai Asymp Sig. (2tailed) sebesar 0,811 yang berarti nilai tersebut di atas nilai signifikan $0,811>0,05$. Dengan demikian dapat dikatakan bahwa variabel residual berdistribusi normal. Untuk uji multikolineritas, menunjukkan bahwa variabel NH Approach dan variabel Return On Asset (ROA) tidak terjadi multikolinearitas. Hal ini dikarenakan nilai tolerance variabel $\mathrm{NH}$ Approach dan variabel Return On Asset (ROA) berada di atas 0,10 atau $0,851>0,10$ dan nilai VIF berada di bawah 10 atau $1,176<10$.

Dari grafik scatterplot terlihat bahwa plot menyebar secara acak di atas maupun di bawah angka nol pada sumbu Regression Studentized Residual. Oleh karena itu, maka berdasarkan uji heteroskedastisitas menggunakan metode analisis grafik, pada model regresi yang terbentuk dinyatakan tidak terjadi gejala heteroskedastisitas. Nilai DurbinWatson dalam penelitian ini adalah sebesar 1,393. Berdasarkan tabel Durbin-Watson diketahui bahwa nilai dU untuk data sebanyak 9 dan variabel independen $(\mathrm{k})=2$ adalah 1,6993. Maka nilai $\mathrm{dL}<$ $\mathrm{dW}<\mathrm{dU}$ atau dapat dijelaskan bahwa 0,6291< 1,393< 1,6993. Dengan demikian dapat dikatakan bahwa autokorelasi tanpa kesimpulan.

\section{b. Deskriptif Kualitatif}

Analisis deskriptif dalam penelitian ini dimaksudkan untuk mendapatkan gambaran atau deskripsi mengenai corporate social responsibility disclosure, return on assets dan nilai perusahaan pada PT. Unilever Indonesia, Tbk yang terdaftar di Bursa Efek Indonesia periode 2006-2014.

1) Corporate Social Responsibility (CSR) Disclosure Pada PT. Unilever Indonesia, Tbk yang Terdaftar Di Bursa Efek Indonesia Periode 2006-2014

Dari hasil penelitian, nilai minimum CSR dengan pengukuran NH Approach pada PT. Unilever Indonesia, Tbk periode 2006-2014 adalah sebesar $70,15 \%$ terdapat pada tahun 2006 , sedangkan nilai maksimum adalah sebesar $73,13 \%$ terdapat pada tahun 2011 dan 2014. Nilai rata-rata CSR adalah sebesar $71,81 \%$. Pada penelitian ini dalam beberapa tahun perusahaan memiliki nilai $\mathrm{NH}$ Approach di atas nilai rata-rata yang berarti pelaksanaan dan pengungkapan corporate social responsibilty yang semakin tinggi maka akan semakin baik kinerja sosial perusahaan terhadap lingkungan sekitar perusahaan.

2) Profitabilitas Pada PT. Unilever Indonesia, Tbk yang Terdaftar Di Bursa Efek Indonesia Periode 2006-2014
Dari hasil penelitian, rata-rata nilai Return on Assets (ROA) pada PT. Unilever Indonesia, Tbk yang terdaftar di Bursa efek Indonesia periode 20062014 adalah sebesar $39,23 \%$. Nilai minimum ROA adalah sebesar 36,84\% terdapat pada tahun 2007 yang berarti penggunaan aset kurang baik karena berada dibawah rata-rata tahun penelitian. Sedangkan nilai maksimum ROA adalah sebesar 42,14\% terdapat pada tahun 2013 yang berarti penggunaan aset perusahaan berada diatas rata-rata tahun penelitian.

\section{3) Nilai Perusahaan Pada PT. Unilever} Indonesia, Tbk yang Terdaftar Di Bursa Efek Indonesia Periode 2006-2014

Dari hasil penelitian, nilai minimum market to book ratio pada PT. Unilever Indonesia, Tbk adalah sebesar $1913,07 \%$ terdapat pada tahun 2007, sedangkan nilai maksimum market to book ratio adalah sebesar 5359,01\% terdapat pada tahun 2014 . Rata-rata nilai market to book ratio adalah sebesar $3252,80 \%$. Hal ini mengindikasikan kemampuan perusahaan dalam meningkatkan nilai perusahaan sebesar 3252,80\% lebih banyak dari nilai buku perusahaan tersebut.

\section{c. Deskriptif Kuantitatif}

\section{1) Analisis Regresi Linier Berganda}

Berdasarkan hasil analisa dengan program SPSS, maka model regresi linear berganda yaitu sebagai berikut: $Y=\mathbf{- 5 3 7 , 2 9 7}+\mathbf{5 6 8 , 9 7 4} \mathrm{X} 1+$ $411,042 \times 2+\varepsilon$

Berdasarkan hasil persamaan regresi di atas maka dapat disimpulkan bahwa terdapat pengaruh positif antara pengungkapan corporate social responsibility disclosure dengan basis NH Approach dan return on assets terhadap maka market to book ratio pada PT. Unilever Indonesia, Tbk yang terdaftar di Bursa Efek Indonesia.

\section{2) Analisa Korelasi dan Determinasi}

Berdasarkan hasil pengolahan data SPSS diperoleh nilai koefisien korelasi adalah sebesar 0,834 . Dengan demikian dapat dikatakan bahwa korelasi atau hubungan antara $\mathrm{NH}$ Approach dan Return On Assets (ROA) terhadap Market to Book Ratio pada PT. Unilever Indonesia, Tbk yang terdaftar di Bursa Efek Indonesia adalah sangat kuat.

Untuk koefisien determinasi adalah sebesar 0,696 yang berarti bahwa Market to Book Ratio dapat dijelaskan oleh NH Approach dan Return On Assets (ROA) sebesar 69,6\% pada PT. Unilever Indonesia, Tbk periode 2006-2014 dan sisanya $30,4 \%$ dijelaskan oleh variabel lain yang tidak dimasukkan dalam model penelitian ini.

\section{3) Uji Hipotesis}

\section{a) Uji Simultan (Uji F)}

Uji statistik $\mathrm{F}$ pada dasarnya menunjukkan apakah semua variabel independen yang dimasukkan dalam model mempunyai pengaruh secara simultan terhadap semua variabel dependen. Tingkat signifikansi yang digunakan adalah sebesar 5\%,

\begin{tabular}{lllll}
\hline \hline Jurnal SULTANIST & ISSN : 2338-4328 & Vol. 4, No. 1, & JUNI 2016 & 61
\end{tabular}


dengan level of confidence 95\% $(\alpha=0,05)$ dan degree of freedom (n-k) dan (k-1), dimana (n) adalah jumlah observasi dan (k) adalah jumlah variabel.

Uji ini dilakukan dengan membandingkan signifikansi $\mathrm{F}_{\text {hitung }}$ dengan $\mathrm{F}_{\text {tabel }}$.

(1) Jika $F_{\text {hitung }}>F_{\text {tabel }}$, atau probabilitas $<0,05$ maka $\mathrm{H}_{0}$ ditolak yang berarti bahwa Corporate Social Responsibility Disclosure dan Profitabilitas berpengaruh signifikan secarasimultan terhadap Nilai Perusahaan pada PT. Unilever Indonesia, Tbk yang terdaftar di Bursa Efek Indonesia.

(2) Jika $\mathrm{F}_{\text {hitung }}<\mathrm{F}_{\text {tabel, }}$, atau probabilitas $>0,05$ maka $\mathrm{H}_{0}$ diterima yang berarti bahwa Corporate Social Responsibility Disclosure dan Profitabilitas berpengaruh tidak signifikan secara simultan terhadap Nilai Perusahaan pada PT. Unilever Indonesia, Tbk yang terdaftar di Bursa Efek Indonesia.

Dari hasil pengolahan data, dapat dilihat bahwa dengan tingkat kepercayaan 95\%, $\mathrm{n}=9, \alpha=$ 0,05 , df $1=\mathrm{k}-1=3-1=2$, df $2=\mathrm{n}-\mathrm{k}=9-3=6$ diperoleh angka $F_{\text {tabel }}$ sebesar 5,14 dan $F_{\text {hitung }}$ sebesar 5,14. Dengan demikian dapat disimpulkan bahwa $F_{\text {hitung }}>F_{\text {tabel }}$ atau $6,856>5,14$ dengan tingkat signifikansi $0,028<0,05$ maka $\mathrm{H}_{0}$ ditolak yang berarti bahwa Corporate Social Responsibility Disclosure dan Profitabilitas secara simultan berpengaruh signifikan terhadap Nilai Perusahaan pada PT. Unilever Indonesia, Tbk yang terdaftar di Bursa Efek Indonesia.

\section{b) Uji Parsial (Uji t)}

Uji t digunakan untuk menguji pengaruh variabel bebas terhadap variabel terikat secara parsial atau individual. Adapun hipotesis yang diuji adalah sebagai berikut :

(1) Apabila $t_{\text {hitung }}>t_{\text {tabel }}$ atau probabilitas $<$ 0,05 berarti $\mathrm{H}_{\mathrm{a}}$ diterima, artinya Corporate Social Responsibility Disclosure dan Profitabilitas berpengaruh signifikan secara parsial terhadap Nilai Perusahaan pada PT. Unilever Indouesia Tbk yang terdaftar di Bursa Efek Indonesia.

(2) Apabila $t_{\text {hitung }}<t_{\text {tobel }}$ atau probabilitas $>$ 0,05 berarti $\mathrm{H}_{0}$ diterima, artinya Corporate Social Responsibility Disclosure dan Profitabilitas berpengaruh tidak signifikan secara parsial terhadap Nilai Perusahaan pada PT. Unilever Indonesia Tbk yang terdaftar di Bursa Efek Indonesia.

Hipotesis digunakan untuk menguji signifikansi koefisien persamaan regresi dirumuskan sebagai berikut :

(1) Jika $t_{\text {hitung }}>t_{\text {tabel }}$ atau probabilitas signifikan $<\alpha$ $(5 \%)$, maka $\mathrm{H}_{0}$ ditolak

(2) Jika $t_{\text {hitung }}<\mathrm{t}_{\text {tabel }}$ atau probabilitas signifikan $>\alpha$ (5\%), maka $\mathrm{H}_{0}$ diterima. berikut:

Dari hasil uji t diperoleh kesimpulan sebagai

(1) Untuk variabel CSR dengan basis $\mathrm{NH}$ Approach dengan derajat signifikansi sebesar
$5 \%$, tingkat kepercayaan $95 \%$ dan degree of freedom $(d f=6)$, diperoleh angka $\mathrm{t}_{\text {tabel }}$ sebesar 2,44691 dan $t_{\text {hitung }}$ sebesar 1,625. Dengan demikian dapat disimpullkan bahwa $\mathrm{t}_{\text {hitung }}<\mathrm{t}_{\text {tabel }}$ atau $1,625<2,44691$ dan tingkat signifikansi $0,155>0,05$ maka $\mathrm{H}_{0}$ diterima yang berarti bahwa secara parsial CSR berpengaruh tidak signifikan terhadap Nilai Perusahaan pada PT. Unilever Indonesia, Tbk yang terdaftar di Bursa Efek Indonesia

(2) Untuk variabel Profitabilitas yang diproksikan dengan Return On Assets (ROA), dengan derajat signifikansi sebesar 5\%, tingkat kepercayaan $95 \%$ dan degree of freedom (n-k$1=9-2-1=6$ ), diperoleh angka $t_{\text {tabel }}$ sebesar 2,44691 dan $t_{\text {hitung }}$ sebesar 1,659. Dengan demikian dapat disimpulkan bahwa $\mathrm{t}_{\text {hitung }}<\mathrm{t}_{\text {tabel }}$ atau 2,440 $<2,44691$ dan tingkat signifikansi 0,05 maka $\mathrm{H}_{0}$ diterima yang berarti bahwa secara parsial profitabilitas berpengaruh tidak signifikan terhadap nilai perusahaan pada PT. Unilever Indonesia, Tbk yang terdaftar di Bursa Efek Indonesia

\section{Evaluasi}

a. Corporate Social Responsibility Disclosure Pada PT. Unilever Indonesia, Tbk yang Terdaftar Di Bursa Efek Indonesia.

Dari hasil penelitian, tingkat pengungkapan CSR dengan pengukuran NH Approach berfluktuasi setiap tahunnya dan cenderung meningkat. Tingkat terendah CSR yaitu sebesar $70,15 \%$. terdapat pada tahun 2006 pada PT. Unilever Indonesia, Tbk yang terdaftar di Bursa Efek Indonesia periode 2006-2014. Sedangkan tingkat tertinggi sebesar $73,13 \%$ pada tahun 2011 dan 2014. Hal ini menunjukkan bahwa pelaksanaan dan pengungkapan CSR di dalam laporan tahunan (апnual report) yang semakin tinggi maka akan semakin baik kinerja sosial perusahaan terhadap lingkungan sekitar perusahaan yang nantinya akan menciptakan kesan positif di mata masyarakat serta mendongkrak reputasi atau citra perusahaan demi peningkatan nilai perusahaan serta menjaga kelangsungan hidup perusahaan.

b. Profitabilitas Pada PT. Unilever Indonesia, Tbk yang Terdaftar Di Bursa Efek Indonesia Dari hasil penelitian, kondisi Return On Assets (ROA) pada PT. Unilever Indonesia, Tbk yang terdaftar di Bursa Efek Indonesia periode 20062014 mengalami fluktuasi. Rata-rata nilai ROA pada PT. Unilever Indonesia, Tbk yang terdaftar di Bursa efek Indonesia periode 2006-2014 adalah sebesar $39,23 \%$. Hal ini menunjukkan bahwa PT. Unilever Indonesia, Tbk periode 2006-2014 mampu memperoleh laba bersih sebesar 39,23\% dibandingkan dengan total asetnya dan dapat dikatakan cukup baik dalam menggunakan aset yang dimiliki untuk menghasilkan laba. 
c. Nilai Perusahaan Pada PT. Unilever Indonesia, Tbk yang Terdaftar Di Bursa Efek Indonesia

Dari hasil penelitian kondisi Market to Book Ratio pada PT. Unilever Indonesia, Tbk yang terdaftar di Bursa Efek Indonesia periode 2006-2014 mengalami fluktuasi tetapi cendrung meningkat. Nilai minimum MBR adalah sebesar 1913,07\% terdapat pada tahun 2007, sedangkan nilai MBR adalah sebesar 5359,01\% terdapat pada tahun 2014 yang berarti perusahaan mampu meningkatkan kinerja perusahaan untuk mengoptimalkan nilai perusahaaan yang akan membuat kemakmuran pemegang saham meningkat. Rata-rata nilai $M B R$ adalah sebesar $3252,80 \%$. Hal ini mengindikasikan kemampuan perusahaan dalam meningkatkan nilai perusahaan sebesar $3252,80 \%$ lebih banyak dari nilai buku perusahaan tersebut.

d. Pengaruh Corporate Social Responsibility (CSR) Disclosure dan Profitabilitas Terhadap Nilai Perusahaan Pada PT. Unilever Indonesia, Tbk yang Terdaftar Di Bursa Efek Indonesia

Berdasarkan hasil pengujian regresi linier berganda, diketahui bahwa CSR dengan basis $\mathrm{NH}$ Approach dan ROA memiliki pengaruh positif terhadap Market to Book Ratio. Hal ini dapat dilihat dari persamaan regresi yaitu $\mathrm{Y}=-537,297+568,974$ $\mathrm{X} 1+411,042 \mathrm{X} 2+\varepsilon$.

Besar pengaruh yang dimaksud adalah variabel CSR dengan basis NH Approach adalah 568,974 yang berarti bahwa setiap kenaikan $\mathrm{NH}$ Approach sebesar 1 satuan, maka akan diikuti kenaikan Market to Book Ratio sebesar 568,974 satuan. Hasil penelitian ini sudah sejalan dengan teori yang dikemukakan oleh Untung (2008:6), yang menyatakan bahwa perusahaan yang melakukan Corporate Social Responsibility Disclosure akan meningkatkan nilai perusahaan dilihat dari harga saham dan laba perusahaan (earning) sebagai akibat dari para investor yang menanamkan saham di perusahaan.

Sementara untuk variabel profitabilitas yang diproksikan dengan Return on assets besar pengaruh yang dimaksud adalah 411,042 yang berarti bahwa setiap kenaikan Return on Assets sebesar 1 satuan maka akan diikuti kenaikan Market to Book Ratio sebesar 411,042 satuan. Hasil penelitian ini sudah sejalan dengan teori yang dikemukakan Achmad (2004:47), yang menyatakan bahwa adanya pertumbuhan return on assets diharapkan terjadi kenaikan harga saham yang lebih besar daripada kenaikan earning. Dengan tingginya profitabilitas yang dihasilkan perusahaan maka akan diikuti oleh semakin tingginya nilai perusahaan tersebut.

\section{KESIMPULAN DAN SARAN}

\section{Kesimpulan}

a. Rata-rata tingkat CSR dengan pengukuran $\mathrm{NH}$ Approach pada PT. Unilever Indonesia, Tbk periode 2006-2014 adalah sebesar 71,81\%. Ratarata nilai ROA adalah sebesar $39,23 \%$. Untuk MBR memiliki nilai rata-rata sebesar $3252,80 \%$.

b. Dari hasil pengujian regresi linear berganda diketahui bahwa CSR dengan basis NH Approach dan ROA memiliki pengaruh yang positif terhadap nilai perusahaan. Hal ini dapat dilihat dari persamaan regresi yaitu $\mathrm{Y}=-537,297+$ $568,97 \mathrm{X} 1+411,042 \mathrm{X} 2+\varepsilon$.

c. Berdasarkan hasil analisis kofisien korelasi diketahui bahwa terdapat hubungan yang sangat kuat antara CSR dengan basis NH Approach dan ROA terhadap Market to Book Ratio yaitu sebesar 0,834 atau 83,4\%. Hasil analisis koefisien determinasi menunjukkan bahwa besar persentase variabel Market to Book Ratio yang dijelaskan oleh NH Approach dan ROA sebesar $69,6 \%$ sedangkan $30,4 \%$ dijelaskan oleh variabel lain yang tidak dimasukkan dalam model penelitian ini.

d. Dari hasil uji statistik $\mathrm{F}$ diperoleh hasil $\mathrm{F}_{\text {hitung }}>$ $F_{\text {tabel }}$ atau $6,856>5,148$ dengan tingkat signifikansi 0,028 maka $\mathrm{H}_{0}$ ditolak yang berarti bahwa corporate social responsibility disclosure dan profitabilitas secara simultan berpengaruh signifikan terhadap nilai perusahaan.

e. Dari hasil uji statistik $\mathrm{t}$ diperoleh hasil bahwa secara parsial untuk variabel $C S R$ dengan basis $\mathrm{NH}$ Approach : $\mathrm{t}_{\text {hitung }}<\mathrm{t}_{\text {tabel }}$ atau 1,625 $<2,44691$ dan tingkat signifikansi $0,155>0,05$, yang berarti bahwa secara parsial $C S R$ berpengaruh tidak signifikan terhadap nilai perusahaan. Sementara untuk variabel $R O A$ ditemukan bahwa $\mathrm{t}_{\text {hitung }}<\mathrm{t}_{\text {tabel }}$ atau 2,440<2,44691 dan tingkat signifikansi 0,05 , yang berarti bahwa secara parsial ROA berpengaruh tidak signifikan terhadap nilai perusahaan.

\section{Saran}

a. Bagi perusahaan, diharapkan penelitian ini dapat menjadi bahan pertimbangan dalam meningkatkan kinerja sosialnya dikarenakan kinerja sosial yang baik dalam suatu perusahaan dapat meningkatkan kepercayaan konsumen sehingga menjadi nilai tambah dalam meningkatkan nilai perusahaan, selain itu efektivitas pengelolaan aset perusahaan dalam menghasilkan laba perlu ditingkatkan.

b. Bagi investor dan calon investor, untuk terlebih dahulu memperhatikan kondisi perusahaan baik dari segi finasial maupun non finasial perusahaan. Hal ini untuk menjamin keberlangsungan usaha perusahaan yang akan menjadi calon investasi bagi para investor tersebut.

c. Bagi peneliti selanjutnya, karena keterbatasan yang dimiliki penulis baik dari waktu, tenaga dan biaya maka penulis menyarankan sebaiknya objek penelitian yang digunakan tidak hanya 
terbatas pada PT Unilever Indonesia, Tbk saja, tetapi menambahkan perusahaan-perusahaan di sektor lain yang terdaftar di Bursa Efek Indonesia agar dapat mengetahui perbandingannya serta memperluas bahasan dengan proksi lain seperti tingkat likuiditas, inflasi, dan pertumbuhan ekonomi.

\section{E. DAFTAR PUSTAKA}

Achmad. 2004. Dasar-dasar Manajemen Investasi dan Portofolio. Jakarta : Rineka Cipta

Brigham, Eugene F., dan Joel F. Houston. 2009. Dasar-dasar Manajemen Keuangan. Edisi 10. Jakarta: Salemba Empat.

Hadi, Nor. 2010. Corporate Social Responsibility. Yogyakarta: Graha Ilmu.
Husnan , S,. dan Pudjiastuti E. 2004. Dasar-dasar Manajemen Keuangan. Edisi keempat, Yogyakarta: UUP AMP YKP.

Kasmir, 2010. Pengantar Manajemen Keuangan. Edisi Pertama. Cetakan Kedua, Jakarta : Prenada Media Group.

Keown, et, al., 2004. Manajemen Keuangan : Prinsip-prinsip Dasar dan Aplikasi. Edisi Kesembilan. Jilid 1, Jakarta : PT. Index Kelompok Gramedia.

Martani, dkk. 2012. Akuntansi Keuangan Menengah Berbasis PSAK, Jakarta: Salemba Empat.

Sudana, I Made. 2011. Manajemen Keuangan Perusahaan. Jakarta: Erlangga.

Untung, Budi. 2008. Corporate Social Responsibility. Jakarta: Sinar Grafika. 